\title{
Lateral Mobility of Nicotinic Acetylcholine Receptors on Neurons Is Determined by Receptor Composition, Local Domain, and Cell Type
}

\author{
Catarina C. Fernandes, ${ }^{1,2}$ Darwin K. Berg, ${ }^{1}$ and David Gómez-Varela ${ }^{1}$ \\ ${ }^{1}$ Neurobiology Section, Division of Biological Sciences, University of California, San Diego, La Jolla, California 92093-0357, and 'Institute of Pharmacology \\ and Neurosciences, Faculty of Medicine and Unit of Neurosciences, Institute of Molecular Medicine, University of Lisbon, 1649-028 Lisbon, Portugal
}

The lateral mobility of surface receptors can define the signaling properties of a synapse and rapidly change synaptic function. Here we use single-particle tracking with Quantum Dots to follow nicotinic acetylcholine receptors (nAChRs) on the surface of chick ciliary ganglion neurons in culture. We find that both heteropentameric $\alpha 3$-containing receptors ( $\alpha 3^{\star}$-nAChRs) and homopentameric $\alpha 7$ containing receptors ( $\alpha 7$-nAChRs) access synaptic domains by lateral diffusion. They have comparable mobilities and display Brownian motion in extrasynaptic space but are constrained and move more slowly in synaptic space. The two receptor types differ in the nature of their synaptic restraints. Disruption of lipid rafts, PDZ-containing scaffolds, and actin filaments each increase the mobility of $\alpha 7$-nAChRs in synaptic space while collapse of microtubules has no effect. The opposite is seen for $\alpha 3^{\star}$-nAChRs where synaptic mobility is increased only by microtubule collapse and not the other manipulations. Other differences are found for regulation of $\alpha 3^{*}$-nAChR and $\alpha 7$-nAChR mobilities in extrasynaptic space. Most striking are effects on the immobile populations of $\alpha 7$-nAChRs and $\alpha 3^{\star}$-nAChRs. Disruption of either lipid rafts or PDZ scaffolds renders half of the immobile $\alpha 3^{\star}$-nAChRs mobile without changing the proportion of immobile $\alpha 7$-nAChRs. Similar results were obtained with chick sympathetic ganglion neurons, though regulation of receptor mobility differed in at least one respect from that seen with ciliary ganglion neurons. Control of $n A C h R$ lateral mobility, therefore, is determined by mechanisms that are domain specific, receptor subtype dependent, and cell-type constrained. The outcome is a system that could tailor nicotinic signaling capabilities to specific needs of individual locations.

\section{Introduction}

Nicotinic cholinergic signaling employs the transmitter acetylcholine (ACh) to activate ligand-gated ion channels, termed nicotinic acetylcholine receptors (nAChRs), which are widely distributed in the nervous system. Signaling through nAChRs contributes to a variety of higher-order functions, including learning and memory (Picciotto et al., 1995; Bannon et al., 1998; Marubio et al., 1999; Bitner et al., 2007), and has been implicated in numerous neurodegenerative disorders (Newhouse et al., 1997; Picciotto and Zoli, 2002; Raggenbass and Bertrand, 2002; Teper et al., 2007; Shinawi et al., 2009) as well as addiction (Mansvelder and McGehee, 2002; Maskos et al., 2005; Zhang et al., 2009).

The effectiveness of nicotinic signaling depends critically on nAChR positioning. Presynaptic locations enable the receptors to

\footnotetext{
Received Dec. 16, 2009; revised May 6, 2010; accepted May 15, 2010.

Grant support was provided by the National Institutes of Health (NS012601, NOS35469, and American Recovery and Reinvestment Act of 2009 stimulus funds) and the Tobacco-Related Disease Research Program (16RT-0167). C.C.F. is a Fundação Calouste Gulbenkian Graduate Fellow; D.G.V. is a Fundación para la Investigación Científica y Técnica Postdoctoral Fellow and a Tobacco-Related Disease Research Program Postdoctoral Fellow. We thank Tobias Köhl for his help and advice on developing tools for analysis of single-particle tracking. We thank Xiao-Yun Wang for expert technical assistance.

Correspondence should be addressed to David Gómez-Varela, Neurobiology Section, Division of Biological Sciences, 0357, University of California, San Diego, 9500 Gilman Drive, La Jolla, CA 92093-0357. E-mail: dgomezvarela@ucsd.edu.

DOI:10.1523/JNEUROSC1.6236-09.2010

Copyright $\odot 2010$ the authors $\quad 0270-6474 / 10 / 308841-11 \$ 15.00 / 0$
}

control transmitter release while postsynaptic locations enable them to modulate transmission in noncholinergic pathways (McGehee et al., 1995; Gray et al., 1996; Alkondon and Albuquerque, 2001; Fabian-Fine et al., 2001; Ji et al., 2001; Le Magueresse et al., 2006; Wanaverbecq et al., 2007; Zhang and Berg, 2007). Positioning relative to intracellular components is also important because nAChR-mediated modulation usually employs calcium-activated mechanisms. Calcium enters directly through homopentameric $\alpha 7$ containing receptors ( $\alpha 7$-nAChRs) (Bertrand et al., 1993; Seguela et al., 1993) and can be recruited indirectly by other nAChRs (DajasBailador and Wonnacott, 2004). The modulation achieved depends on the regulatory pathway engaged, and that often depends on the calcium-dependent machinery linked to the $\mathrm{AChR}$ being activated.

Postsynaptic scaffold components and associated transmembrane proteins are likely to help localize $\mathrm{nAChRs}$ at synaptic sites (Conroy et al., 2003, 2007; Parker et al., 2004; Temburni et al., 2004; Farías et al., 2007; Rosenberg et al., 2008), but the receptors may remain mobile. Muscle nAChRs are mobile on the cell surface (Anderson and Cohen, 1977; Axelrod et al., 1978; Young and Poo, 1983; Akaaboune et al., 2002), as are neuronal nAChRs (McCann et al., 2008). Rapid lateral mobility of glutamate receptors defines key signaling features at glutamate synapses (Heine et al., 2008; Newpher and Ehlers, 2008; Triller and Choquet, 2008; Makino and Malinow, 2009).

Here we use single-particle-tracking techniques with Quantum Dot (QD) nanocrystals (Heine et al., 2008; Triller and Choquet, 
2008) to follow individual nAChRs on the surface of chick ciliary ganglion (CG) neurons in culture. The neurons form nicotinic cholinergic synapses on each other under these conditions and express the same two classes of receptors found in vivo: homopentameric $\alpha 7$-nAChRs and heteropentameric $\alpha 3^{\star}$-nAChRs (Margiotta and Berg, 1982; Vernallis et al., 1993; Chen et al., 2001). We find that both classes of receptors slow down when transiting synaptic space. In addition, a fraction of each receptor type is immobile and preferentially localized in synaptic space. Disrupting either the cytoskeleton or postsynaptic scaffolds differentially affects $\alpha 7$-nAChRs and $\alpha 3^{*}$ nAChRs. Similar results were obtained with sympathetic neurons, though one mechanism of receptor restraint differed. Subunit composition and cell type, therefore, can determine the surface fate of nAChRs, linking them to different organizing elements. This, in turn, can provide a mechanism for targeting individual nAChR subtypes to specific job assignments.

\section{Materials and Methods}

Cell cultures. Dissociated embryonic day 8 (E8) chick CG neurons were grown in culture for $6 \mathrm{~d}$ on glass bottom culture dishes coated with poly-D-lysine, fibronectin, and lysed fibroblasts at 2 ganglion equivalents per $16 \mathrm{~mm}$ coverslip (Nishi and Berg, 1981; Zhang et al., 1994). Dissociated E13 chick sympathetic ganglion neurons from the lumbar region were grown in culture for $6 \mathrm{~d}$ on glass bottom culture dishes coated with poly-D-lysine at 1.5 ganglion equivalents per $16 \mathrm{~mm}$ coverslip (Downing and Role, 1987).

Transfections. Neurons were transfected at the time of plating as described previously (Conroy et al., 2003) using the transfection reagent Effectene (0.25-0.5 $\mu \mathrm{g}$ of DNA/well, 1:25 ratio of DNA/Effectene, Qiagen). The medium was replaced $24 \mathrm{~h}$ after plating, and cultures were analyzed after 6 d. Typical transfection efficiencies were 1-2\%.

Pharmacological manipulations. Actin filaments were depolymerized by treating cultures with latrunculin A $(3 \mu \mathrm{M})$ or cytochalasin D $(2 \mu \mathrm{M})$, and microtubules were depolymerized by treatment with nocodazole (10 $\mu \mathrm{M})$ —all for $1 \mathrm{~h}$ at $37^{\circ} \mathrm{C}$ in $0.1 \%$ DMSO. For cholesterol depletion, cells were incubated for $2.5 \mathrm{~h}$ with cholesterol oxidase (COase, $2 \mathrm{U} / \mathrm{ml}$ ) or with methyl- $\beta$-cyclodextrin $(\mathrm{M} \beta \mathrm{CD}, 3 \mu \mathrm{M})$ for $15 \mathrm{~min}$ at $37^{\circ} \mathrm{C}$.

Single-particle tracking. QDs (Invitrogen) tethered to individual $\alpha 3^{*}$ - and $\alpha 7$-nAChRs via specific biotinylated ligands were used as fluorescent probes to follow the mobility of nAChRs. Synapses were labeled using either FM4-64 dye uptake (5 $\mu \mathrm{M}$, Invitrogen) or MitoTracker 580 staining (100 nM, Invitrogen). FM4-64 labeling was achieved by a $30 \mathrm{~s}$ incubation at room temperature (RT) with $40 \mathrm{~mm} \mathrm{KCl}$ added to the culture medium to stimulate vesicle recycling. MitoTracker Red 580 staining was performed by adding the reagent to the culture medium for $2 \mathrm{~min}$ at $37^{\circ} \mathrm{C}$, washing two times with culture media, and leaving the neurons an additional $30 \mathrm{~min}$ at $37^{\circ} \mathrm{C}$. After rinsing three times with PBS containing $0.1 \% \mathrm{BSA}$, neurons were incubated with either biotinylated $\alpha$-bungarotoxin (Biot- $\alpha$ Bgt, $10 \mathrm{~nm}$, Invitrogen) or biotinylated monoclonal antibody (mAb) 35 (Biot-mAb 35, $0.1 \mu \mathrm{g} / \mathrm{ml}$ ) for 5 min on ice, washed three times, and then incubated for $5 \mathrm{~min}$ with $0.5 \mathrm{~nm}$ streptavidin-coated QDs ( $605 \mathrm{~nm}$ ) on ice. Neurons were washed three times with recording medium containing the following (in $\mathrm{mm}$ ): $160 \mathrm{NaCl}, 10$ HEPES, 10 glucose, $4.5 \mathrm{KCl}, 2 \mathrm{CaCl}_{2}$, and $1 \mathrm{MgCl}_{2}$, $\mathrm{pH}$ 7.4. Negative controls substituted mAb 35 for Biot-mAb 35 (supplemental Fig. $1 A, C$, available at www.jneurosci.org as supplemental material) and used $100 \mu \mathrm{M}$ nicotine to compete the Biot- $\alpha$ Bgt (supplemental Fig. $2 A, C$, available at www. jneurosci.org as supplemental material). To minimize tracking internalized QD-nAChRs, all movies were confined to a 20 min period immediately after the labeling (Charrier et al., 2006). Treating the cells with an acid wash (30 s at pH 5.5 at RT) (Ehlers et al., 2007) removed the vast majority of QDs, confirming that little, if any, internalization had occurred (supplemental Figs. $1 B, D, 2 B, D$, available at www.jneurosci.org as supplemental material).

Neurons were imaged with an inverted microscope (Zeiss Axiovert $200 \mathrm{M}$ ) equipped with a $63 \times$ oil-immersion objective (numerical aperture $=1.40$ ). Samples were illuminated with a mercury lamp and imaged with appropriate excitation filters, dichroic mirrors, and emission filters. Settings were HQ545/30, Q565LP, and HQ610/75M, respectively, for
FM4-64 and MitoTracker; D420/40×, 470DCXR, and D605/40, respectively, for QD 605; and HQ487/25, Q505LP, and HQ535/40M, respectively, for GFP. Fluorescence images were acquired with 95 ms exposure times at $10 \mathrm{~Hz}$ using a CCD camera (AxioCam MRm, Zeiss) and AxioVision 4.6 software (Zeiss).

Single QDs were identified by their characteristic blinking. Tracking of single QDs was performed with the Image (NIH) plugin "SpotTracker" after processing image sequences with the "SpotEnhancing Filter" plugin (Sage et al., 2005). To assign synaptic localizations, trajectories were sorted into extrasynaptic and synaptic bins defined by the mitochondria marker MitoTracker or the FM4-64 dye images. Synaptic spaces for MitoTracker and FM4-64-labeled boutons were defined as punctate regions 3 pixels in diameter $(0.2 \mu \mathrm{m} /$ pixel) (Aravanis et al., 2003). Synaptic and extrasynaptic trajectories were considered for 10 or more consecutive frames each, with the center of the QD inside the respective region. Periods where the fluorescence signal disappeared due to the blinking of single quantum dots were omitted from the analysis. In such cases, the trajectory was reconstructed by joining trajectory fragments immediately before and after the dark period of the blink. Instantaneous diffusion coefficients $\left(D_{\mathrm{i}}\right)$ were determined for each trajectory as previously described (Gómez-Varela et al., 2010), fitting the first five points of the mean square displacement (MSD) curves versus the lag time. The global localization accuracy was determined by testing the vibrational stability of the setup, calculating MSD for immobile spots. Immobile QDs were defined as streptavidin-QDs stationary on the surface of glass bottom dishes in the absence of neurons. The localization accuracy was $50 \mathrm{~nm}$, and the resolution limit in terms of diffusion coefficients was $0.008 \mu \mathrm{m}^{2} / \mathrm{s}$.

Synaptic dwell time was calculated as the total time spent by a QD-nAChR in synaptic space divided by the number of exits by the QD from the space. The frequency of transitions represents the sum of entries and exits from synaptic space divided by the duration of the recording period.

Immunostaining and confocal imaging. To label surface $\alpha 3^{*}$-nAChRs, neurons were lightly fixed with $0.15 \%$ paraformaldehyde (PFA) for $20 \mathrm{~min}$ at $\mathrm{RT}$, washed in PBS, and incubated with mAb 35 (1:200) for $1 \mathrm{~h}$ at RT (Conroy and Berg, 1998). A 45 min incubation with rhodamine- $\alpha$ Bgt (100 $\mathrm{nM}$; Invitrogen) was used to label $\alpha 7$-nAChRs before fixation as previously described (Conroy et al., 2003). After washing in PBS, cells were then fixed with 2\% PFA in PBS for 20 min at RT. To label synaptic boutons, cells were incubated with the anti-synaptotagmin mAb 48 (1:20; Developmental Studies Hybridoma Bank, University of Iowa Department of Biological Sciences) and anti-SV2 antibody (1:1000; Developmental Studies Hybridoma Bank) overnight at $4{ }^{\circ} \mathrm{C}$ in PBS containing 5\% normal donkey serum and $0.1 \%$ Triton X-100. After washing in PBS, cells were incubated with appropriate donkey Cy3- or FITC-conjugated secondary antibody $1 \mathrm{~h}$ at RT (1:250, Jackson ImmunoResearch Laboratories), rinsed, and mounted on slides for imaging.

Confocal images were acquired in sequential mode using a Leica SP5 confocal microscope with settings that did not saturate the fluorescence signals and that fulfilled Nyquist sampling criteria. ImageJ software was used for quantifying the labeling intensity and the alignment of receptor clusters with SV2/synaptotagmin puncta. For this analysis, regions of interest (ROIs) of $20 \mu \mathrm{m}$ were selected on the neurites. ROIs were binarized automatically using the mean of the background value inside the neurite plus two times the SD as an intensity threshold value for defining a cluster or puncta in each image. Clusters/puncta within the ROIs were registered if they had at least $3 \times 3$ pixels above threshold (pixel diameter: $80 \mathrm{~nm}$ ). Receptor clusters were considered synaptic if they were $\leq 2$ pixels away from SV2/synaptotagmin puncta. Data are expressed as the mean + SEM per neurite length of $10 \mu \mathrm{m}$.

Statistical analysis. Statistical analysis was assessed with Mann-Whitney $U$ test (MW test) for comparisons of diffusion coefficients if single pairs were involved; Kruskal-Wallis test (KW test) was used for $\geq 3$ values. Student's $t$ test ( $t$ test) was used for comparisons of dwell times, numbers of transitions, and immunostaining data if single pairs were involved; one-way ANOVA was used for $\geq 3$ values. The $n$ values report the number of QDs or trajectories examined. ${ }^{\star} p<0.05,{ }^{* *} p<0.01,{ }^{* * *} p<0.001$.

Materials. White leghorn chick embryos were obtained locally and maintained at $37^{\circ} \mathrm{C}$ in a humidified incubator. Biot-mAb 35 was prepared by incubating $\mathrm{mAb} 35$ with a sulfosuccinimidobiotin reagent 
(Pierce via Thermo Scientific). All reagents were purchased from Sigma unless otherwise indicated. The mAb 48 and SV2 antibodies, developed by L. Reichardt and K. Buckley, respectively, were obtained from the Developmental Studies Hybridoma Bank developed under the auspices of the National Institute of Child Health and Human Development and maintained by the University of Iowa Department of Biology (Iowa City, IA).

\section{Results}

\section{Lateral mobility of nicotinic receptors on neurons}

To examine the lateral mobility of nAChRs on neurites of $\mathrm{CG}$ neurons in culture, we labeled $\alpha 3^{\star}$-nAChRs with Biot-mAb 35 and $\alpha 7$-nAChRs with Biot- $\alpha$ Bgt. The labeled receptors were then tracked by incubating them with QDs linked to streptavidin. The labeling was specific because few QDs were observed for $\alpha 3^{*}$ nAChR labeling if the Biot-mAb 35 was replaced with unconjugated mAb 35 (supplemental Fig. 1, available at www.jneurosci. org as supplemental material). Similarly, few QDs were observed for $\alpha 7$-nAChR labeling if the Biot- $\alpha$ Bgt was competed with nicotine (supplemental Fig. 2, available at www.jneurosci.org as supplemental material). Bound QDs were confirmed as being on the cell surface throughout the imaging period in both cases by showing that they could be readily stripped at the end by acid wash (supplemental Figs. 1, 2, available at www.jneurosci.org as supplemental material).

Focusing on single nAChR-QD complexes as evidenced by their characteristic blinking, we tracked the movement of $\alpha 3^{*}$ nAChRs that crossed a synaptic/extrasynaptic border at least twice during their trajectory (Fig. 1A; supplemental Movie 1, available at www.jneurosci.org as supplemental material). Synaptic sites were identified for this purpose by prelabeling either with FM4-64 uptake or MitoTracker staining. Plots of MSD versus lag time were used to examine mobility quantitatively (Fig. $1 B, C$ ). The initial slope yielded the $D_{\mathrm{i}}$ for $\alpha 3^{*}$-nAChRs: $0.070 \mu \mathrm{m}^{2} / \mathrm{s}$ in synaptic space and $0.188 \mu \mathrm{m}^{2} / \mathrm{s}$ in extrasynaptic space (Fig. $1 D, E)$ ( $p<0.001$ for synaptic vs extrasynaptic, MW test). The results were unchanged by a 10 -fold reduction in Biot-mAb 35 concentration used to label the receptors, indicating that antibody-receptor cross-linking was unlikely to have skewed the results (data not shown). Thus mobile $\alpha 3^{*}$-nAChRs displayed significantly decreased diffusion rates when in synaptic locations. The linear MSD plot for extrasynaptic space indicated Brownian motion, whereas the asymptotic plot in synaptic space is consistent with constrained motion (Kusumi et al., 1993).

On adult CG neurons in vivo, $\alpha 7$-nAChRs are largely confined to perisynaptic regions (Jacob and Berg, 1983; Wilson Horch and Sargent, 1995; Shoop et al., 1999, 2002). In cell culture, we find that some $\alpha 7$-nAChR puncta on neurites appear to be associated with synaptic sites defined by SV2 and synaptophysin immunostaining ( $42.4 \pm 4.4 \%, n=22$ image, 3 culture platings) (supplemental Fig. 3, available at www.jneurosci.org as supplemental material), though the staining may reflect in part perisynaptic receptors at the ultrastructural level. QD tracking of mobile $\alpha 7$ nAChRs demonstrated that the receptors traverse both synaptic and extrasynaptic space in neurites and do so with diffusion rates almost equivalent to those found for $\alpha 3^{\star}$-nAChRs (Fig. $2 A$; supplemental Movie 2, available at www.jneurosci.org as supplemental material). The median $D_{\mathrm{i}}$ was $0.067 \mu \mathrm{m}^{2} / \mathrm{s}$ for $\alpha 7$ nAChRs at synaptic sites and $0.188 \mu \mathrm{m}^{2} / \mathrm{s}$ in extrasynaptic regions ( $p<0.001$, MW test). MSD plots again indicated Brownian motion in extrasynaptic space and restricted motion in synaptic space (Fig. $2 B, C$ ). Interestingly, $\alpha 7$-nAChRs clearly differed from $\alpha 3^{\star}$-nAChRs in the frequency with which they crossed into and out of synaptic space (Fig. $2 D$ ): $48.2 \pm 2.5$ and $36.6 \pm$
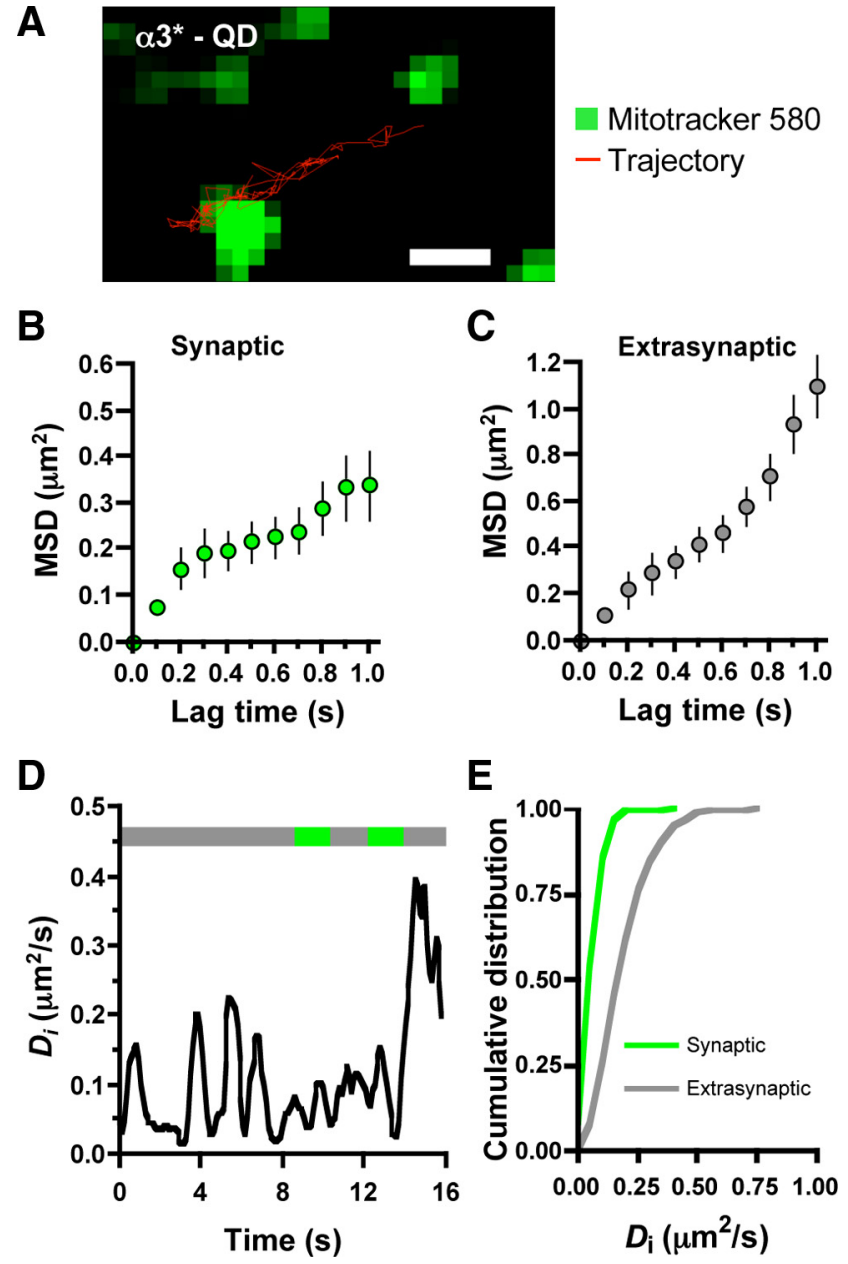

Figure 1. Different mobilities of surface $\alpha 3^{*}$-nAChRs in synaptic and extrasynaptic spaces. A, Trajectory (16s) of a QD- $\alpha 3^{*}-n A C h R$ (red) along a neurite punctuated with synapses stained with MitoTracker (green). Scale bar: $1 \mu \mathrm{m} . \boldsymbol{B}, \boldsymbol{C}$, MSD as a function of time interval for synaptic and extrasynaptic portions of the trajectories (means \pm SDs). $\boldsymbol{D}$, Instantaneous $D_{\mathrm{i}}$ values as a function of time along the trajectory. Top line indicates position of QD- $\alpha 3^{*}-n A C h R$ in extrasynaptic (gray) or synaptic (green) domains. $\boldsymbol{E}$, Cumulative distribution of the instantaneous diffusion coefficients of synaptic (green) and extrasynaptic (gray) $\alpha 3^{*}$-nAChRs ( $n=407$ and 567 for synaptic and extrasynaptic trajectories, respectively, from 5 separate platings; $p<0.001$, MW test).

3.0 transitions/min for $\alpha 3^{*}$ - and $\alpha 7$-nAChRs, respectively $(p<$ $0.01, t$ test). They did not show a significant difference in synaptic dwell time: $0.50 \pm 0.03 \mathrm{~ms}$ and $0.59 \pm 0.04 \mathrm{~ms}$ for $\alpha 3^{\star}$ - and $\alpha 7$-nAChRs, respectively $(n=86,57)$. Results were the same for synapses marked with MitoTracker staining or with FM4-64 uptake (supplemental Fig. 4, available at www.jneurosci.org as supplemental material).

Most striking, however, was the difference between $\alpha 3^{*}$ nAChRs and $\alpha 7$-nAChRs on the neurites when immobile receptors were considered (Fig. $2 D$ ). Only $34 \pm 4 \%$ of all $\alpha 3^{*}$-nAChRs were mobile compared with $61 \pm 3 \%$ of $\alpha 7$-nAChRs $(p<0.05$, $t$ test). The remainder showed no detectable mobility during the entire time of imaging. Approximately half of the total immobile receptors, both for $\alpha 3^{\star}$-nAChRs and for $\alpha 7$-nAChRs, were synaptic ( 46 and $54 \%$, respectively). Given that synaptic membrane occupies $6.4 \pm 0.3 \%$ of the neurite surface $(n=5$ visual fields of GFP-expressing neurites and MitoTracker-stained synapses), immobile receptors appear to be preferentially concentrated at synapses ( $\geq 7$-fold in number per unit area over that in extrasynaptic space). 
A

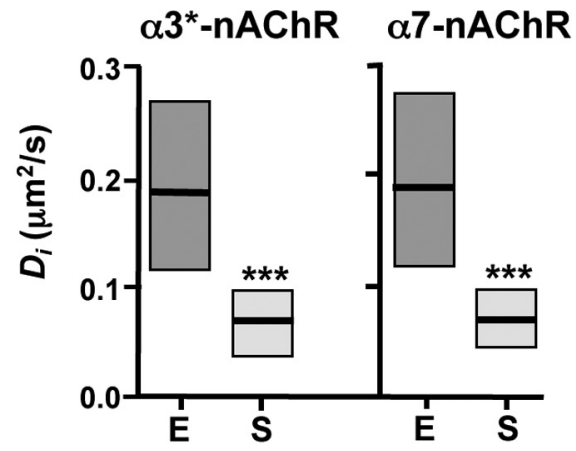

B

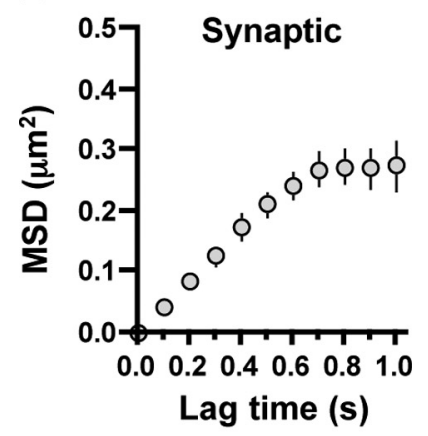

C

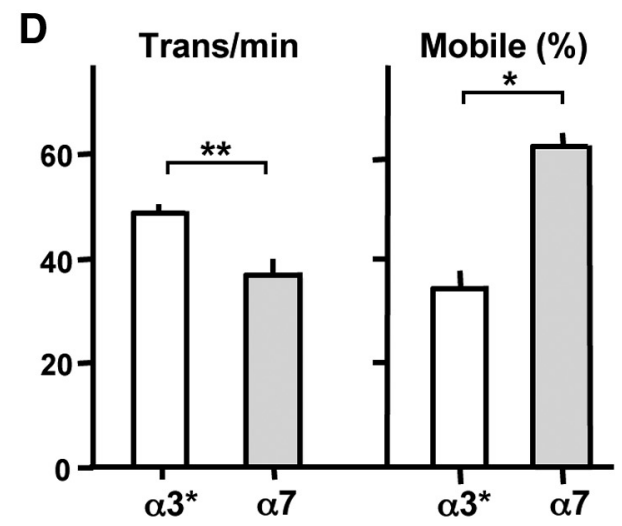

Figure 2. Relative mobilities of $\alpha 3^{*}$-nAChRs and $\alpha 7$-nAChRs. A, Median $D_{\mathrm{i}}$ values ( \pm 25 $75 \%$ interquartile range) of $\alpha 3^{*}$ - and $\alpha 7$-nAChRs in synaptic (S) and extrasynaptic (E) space (from $407 \mathrm{~S}$ and $567 \mathrm{E}$ trajectories for $\alpha 3^{*}$-nAChRs; $197 \mathrm{~S}$ and $312 \mathrm{E}$ for $\alpha 7$-nAChRs). B, C, MSD plots versus time for synaptic and extrasynaptic portions of $\alpha 7$-nAChR trajectories (means \pm SDs). $\boldsymbol{D}$, Transition frequency (trans/min) between synaptic and extrasynaptic space for $\alpha 3^{*}$ nAChRs $\left(\alpha 3^{*}\right)$ and $\alpha 7$-nAChRs $(\alpha 7 ; n=86,57$ QDs) and proportion (mobile \%) of mobile $\alpha 3^{*}$-nAChRs and $\alpha 7$-nAChRs ( $n=124,245$ total QDs, from 2-5 separate platings). Values in $\boldsymbol{D}$ are means \pm SEMs.

The results indicate that mobile $\alpha 3^{*}$-nAChRs and $\alpha 7$ $n A C h R s$ display equivalent diffusion rates in extrasynaptic space and that the synaptic domain restrains their mobility. Additional constraints render a portion of the receptors persistently immobile and collect a significant fraction of such receptors at synapses. This immobility involves a larger fraction of $\alpha 3^{*}$-nAChRs than $\alpha 7$-nAChRs, demonstrating the relevance of subunit composition for nicotinic receptor fate on neurites.

Cytoskeletal determinants of nAChR mobility

Cytoskeletal elements such as microtubules and F-actin can influence the mobility of membrane components on the surface of neurites, differentially affecting receptors in synaptic and extrasynaptic domains (Charrier et al., 2006; Renner et al., 2009). To determine whether microtubules play such a role for nicotinic

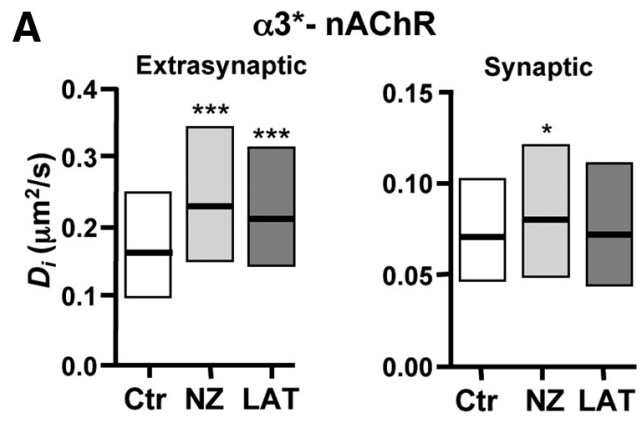

B
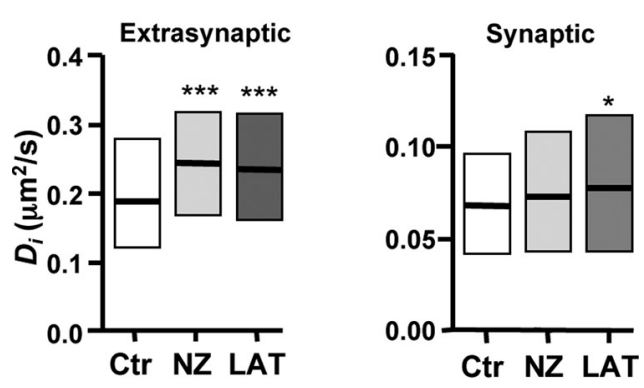

C

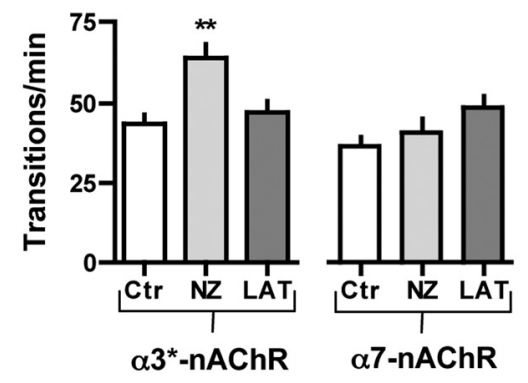

Figure 3. Different cytoskeletal regulation for $\alpha 3^{*}-n A C h R$ and $\alpha 7-n A C h R$ lateral diffusion. QD-nAChR trajectories were examined in extrasynaptic and synaptic space for control conditions (Ctr, $0.1 \%$ DMSO) or after disruption of microtubules with nocodazole (10 $\mu \mathrm{M}, \mathrm{NZ})$ or F-actin with latrunculin $\mathrm{A}(3 \mu \mathrm{M}, \mathrm{LAT})$. $A$, Median $D_{\mathrm{i}}$ values ( $\pm 25-75 \%$ interquartile range) for $\alpha 3^{*}$-nAChRs ( $n=179-343$ trajectories). $\boldsymbol{B}$, Values for $\alpha 7$-nAChRs (86-381 trajectories). $C$, Transition frequency between synaptic and extrasynaptic space $(n=27-56$ QDs from $2-3$ separate platings).

receptors, we incubated CG neurons with nocodazole $(10 \mu \mathrm{M})$ for $1 \mathrm{~h}$ to depolymerize them and used QD trafficking to follow $\alpha 3^{*}$-nAChRs on the neurite surface. The vehicle, DMSO, had no effect except for a minor slowing of extrasynaptic $\alpha 3^{*}$-nAChRs (supplemental Fig. 5, available at www.jneurosci.org as supplemental material); all subsequent comparisons were made against vehicle-treated controls. Nocodazole increased the mobility of the $\alpha 3^{*}$-nAChRs both in synaptic and extrasynaptic space (Fig. $3 A$ ). The median $D_{\mathrm{i}}$ values were $0.079 \mu \mathrm{m}^{2} / \mathrm{s}$ and $0.230 \mu \mathrm{m}^{2} / \mathrm{s}$, respectively; both were significantly different from those in vehicle $(p<0.01$ and 0.001 ; KW test $)$. Microtubule depolymerization also increased the frequency of transitions between the two domains (Fig. 3C): $64 \pm 4$ and $43 \pm 3$ transitions/min with and without nocodazole treatment, respectively ( $p<0.01$; one-way ANOVA). No significant change was seen in the synaptic dwell time (supplemental Fig. 6A, available at www.jneurosci.org as supplemental material). Collapse of filamentous actin (F-actin) by treating with latrunculin A $(3 \mu \mathrm{M})$ for $1 \mathrm{~h}$ also increased the mobility of $\alpha 3^{*}$-nAChRs in extrasynaptic space (Fig. 3A). The median $D_{\mathrm{i}}$ was $0.210 \mu \mathrm{m}^{2} / \mathrm{s}(p<0.001$ compared to vehicle; $\mathrm{KW}$ 
A

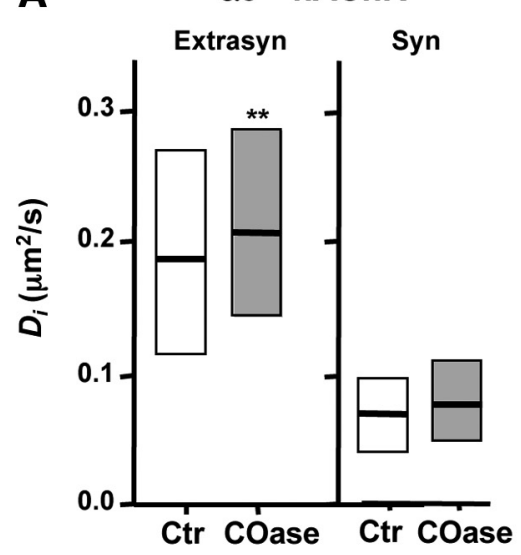

C

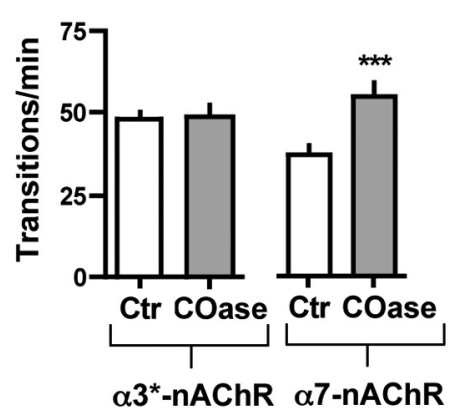

E

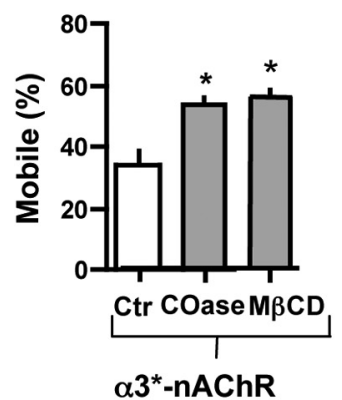

B

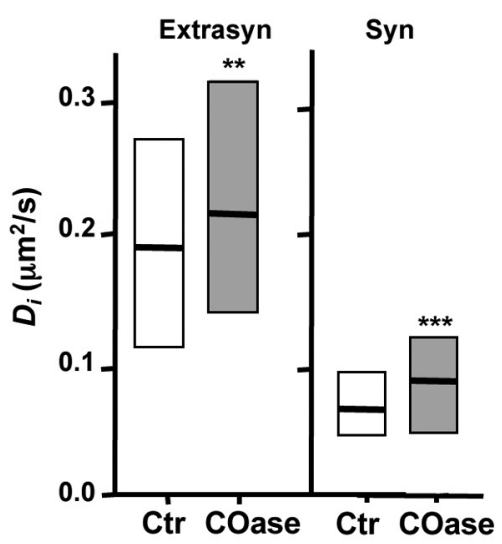

D

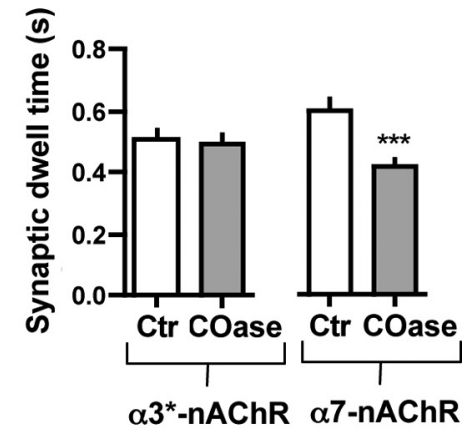

$\mathbf{F}$

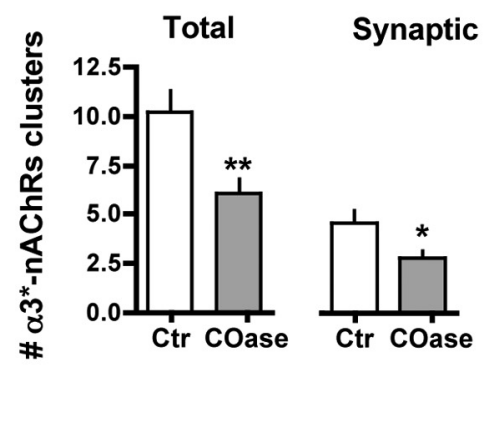

Figure 4. Selective effects of cholesterol depletion. QD-nAChR trajectories were examined in extrasynaptic and synaptic space for control conditions (Ctr) or after cholesterol depletion with either COase or M $\beta C D$. A, Median $D_{\mathrm{i}}$ values for $\alpha 3^{*}-\mathrm{nAChRs}$ ( $\pm 25-$ $75 \%$ interquartile range; $n=167-567$ trajectories). $\boldsymbol{B}$, Values for $\alpha 7$-nAChRs ( $n=171-312)$. C, Transition frequency $(n=$ 38 -86). D, Synaptic dwell time $(n=38-86)$. $E$, Proportions of mobile $\alpha 3^{*}$-nAChRs and $\alpha 7-n A C h R s(n=124-245$ total QDs, from 2-5 separate platings). $\boldsymbol{F}$, Number of total (left) and synaptic (right) $\alpha 3^{*}$-nAChRs clusters expressed per $10 \mu \mathrm{m}$ segment of neurite. In $\boldsymbol{C}-\boldsymbol{F}$, values represent means \pm SEMs taken from $n \geq 3$ separate platings.

test). The treatment did not, however, change the fraction of mobile $\alpha 3^{*}$-nAChRs or their synaptic transitions or dwell time (Fig. $3 A, C$; supplemental Fig. $6 A$, available at www.jneurosci.org as supplemental material).

Both nocodazole and latrunculin A also affected $\alpha 7$-nAChRs, with only minor differences from that seen for $\alpha 3^{*}$-nAChRs. Thus nocodazole increased the diffusion of $\alpha 7$-nAChRs in extrasynaptic regions; the $D_{\mathrm{i}}$ was $0.242 \mu \mathrm{m}^{2} / \mathrm{s}$ ( $p \leq 0.001$ compared to vehicle; KW test). But unlike its effects of $\alpha 3^{*}$-nAChRs, nocodazole had no effect on $\alpha 7$-nAChR diffusion in synaptic space or on the number of synaptic transitions (Fig. $3 B, C$; supplemental Fig. $6 A$, available at www.jneurosci.org as supplemental material). Collapse of F-actin with latrunculin A increased the mobility of $\alpha 7$-nAChRs in both domains (Fig. $3 B$ ), whereas only extrasynaptic $\alpha 3^{*}$-nAChRs were affected in this case. Median $D_{\mathrm{i}}$ values of
$0.078 \mu \mathrm{m}^{2} / \mathrm{s}$ and $0.233 \mu \mathrm{m}^{2} / \mathrm{s}$ were obtained for $\alpha 7$-nAChRs in synaptic and extrasynaptic space, respectively $(p<0.05$, $p<0.001$ vs vehicle; KW test). As found for nocodazole, latrunculin A had no effect on the frequency of transitions between the two domains (Fig. 3C) or the synaptic dwell time (supplemental Fig. $6 \mathrm{~A}$, available at www.jneurosci.org as supplemental material). Neither nocodazole nor latrunculin A treatment changed the proportions of $\alpha 3^{*}$-nAChRs and $\alpha 7$ nAChRs that remained immobile (supplemental Fig. 6B, available at www. jneurosci.org as supplemental material). Cytochalasin, used as an alternative method of disrupting F-actin, similarly failed to alter the proportion of $\alpha 3^{*}$-nAChRs that were mobile (supplemental Fig. $6 B$, available at www.jneurosci.org as supplemental material).

The results indicate that both microtubules and F-actin influence the mobility of nAChRs on neurites and exert subtle differences depending on synaptic versus extrasynaptic locations for $\alpha 3^{*}$-nAChRs and $\alpha 7$-nAChRs. Neither microtubule nor F-actin constraints, however, can account for the fact that a fraction of $\alpha 3^{*}$ nAChRs and $\alpha 7$-nAChRs are immobile.

\section{Effects of cholesterol depletion on receptor mobility}

Lipid rafts, which are membrane microdomains rich in cholesterol and glycosphingolipids, can influence the distribution of surface components (Edidin, 2003; Marguet et al., 2006; Renner et al., 2009). On CG neurons in vivo, lipid rafts engulf and help stabilize $\alpha 7$-nAChRs (Brusés et al., 2001; Liu et al., 2008). We depleted lipid rafts by incubating $C G$ neurons with cholesterol oxidase (COase, $2 \mathrm{U} / \mathrm{ml}$ ), which catalyzes the oxidation of cholesterol to cholestenone and disperses lipid microdomains (Scheiffele et al., 1997; Harder et al., 1998; Keller and Simons, 1998). The treatment increased the mobility of $\alpha 3^{\star}$-nAChRs in the extrasynaptic space (median $D_{\mathrm{i}}=$ $0.208 \mu \mathrm{m}^{2} / \mathrm{s} ; p<0.01$ compared to vehicle; MW test) but had no effect on synaptic $\alpha 3^{*}$-nAChR mobility, transitioning, or dwell time (Fig. $4 A, C, D$ ).

In contrast, lipid raft disruption had extensive effects on $\alpha 7$ nAChRs. Diffusion speeds were increased both within and outside of synaptic spaces (Fig. $4 B$ ). Median $D_{\mathrm{i}}$ values were 0.091 $\mu \mathrm{m}^{2} / \mathrm{s}$ and $0.213 \mu \mathrm{m}^{2} / \mathrm{s}$ for synaptic and extrasynaptic space, respectively ( $p<0.001, p<0.01$ compared to vehicle; MW test). In addition, $\alpha 7$-nAChRs underwent more transitions into and out of synaptic space (Fig. $4 C): 55 \pm 4$ transitions/min $(p<$ $0.001 ; t$ test). They also displayed a reduced dwell time at synapses (Fig. $4 D$ ): $0.42 \pm 0.02 \mathrm{~s}(p<0.001 ; t$ test $)$.

Unexpectedly, lipid raft disruption substantially increased the proportion of $\alpha 3^{*}$-nAChRs that displayed mobility (Fig. $4 E$ ), 
increasing it from $34 \pm 4 \%$ in controls to $54 \pm 2 \%(p<0.05 ; t$ test $)$ on neurites of COase-treated cells. A second method of disrupting lipid rafts, namely treating cells with $M \beta C D$, had the same effect as COase; it increased the proportion of mobile $\alpha 3^{\star}$-nAChRs to the same extent. COase treatment had no effect on the proportion of $\alpha 7$-nAChRs that were mobile (Fig. $4 E$ ). Together, the results indicate multiple effects of the lipid environment on the mobility of nAChRs. It can immobilize a fraction of receptors depending on their subunit composition (e.g., $\alpha 3^{*}$ nAChRs, but not $\alpha 7$-nAChRs) while having little effect on the diffusion of synaptic $\alpha 3^{*}$ nAChRs once mobile. Paradoxically, the lipid raft appears to have greatest effect on the diffusion of $\alpha 7$-nAChRs, retarding them both in synaptic and extrasynaptic space, but apparently does not provide the restraint that holds a fraction of $\alpha 7$-nAChRs immobile on the surface.

Immobility may be the most relevant criterion for stabilizing receptors at postsynaptic sites. The COase treatment, which decreased the number of immobile $\alpha 3^{*}$-nAChRs, also substantially reduced the number of $\alpha 3^{*}$-nAChR clusters on the cell surface (supplemental Fig. 7, available at www.jneurosci.org as supplemental material). These included clusters at synaptic sites as defined by proximity to presumptive presynaptic puncta that costained for SV2 and synaptophysin (Fig. 4F). COase produced no decrement in the number of SV2/synaptophysin puncta, arguing against a major presynaptic effect $(6.2 \pm 0.6$ and $6.5 \pm 0.5$ for controls and COase, respectively; $n=3$ platings). Nor did it reduce the number of $\alpha 7$-nAChR puncta $(6.8 \pm 0.8$ and $7.6 \pm 0.5$ for controls and COase, respectively; $n=3$ platings). No change was seen in the mean size or staining intensity for the remaining puncta in any case (data not shown). The results are most consistent with the lipid environment providing a restraining component that facilitates immobilization of $\alpha 3^{\star}$ nAChRs; release of the constraint tips the balance in favor of dispersal and/or removal.

\section{Constraint of nicotinic receptors by the PDZ-containing postsynaptic scaffold}

Members of the PSD-95 family of PDZ-containing proteins establish postsynaptic scaffolds associated with nicotinic receptors on neurons and influence their signaling and localization (Conroy et al., 2003, Parker et al., 2004; Temburni et al., 2004; McCann et al., 2008). To test the extent to which these PDZproteins may constrain the lateral mobility of nAChRs, we transfected CG neurons with a construct encoding a 9 aa fragment of CRIPT that recognizes the PDZ3 domain of PSD-95 family members and interferes with their ability to form clusters (Passafaro et al., 1999; Conroy et al., 2003). Results were compared both to

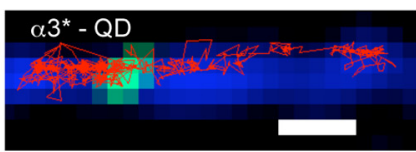

Mitotracker 580

CRIPT

- Trajectory

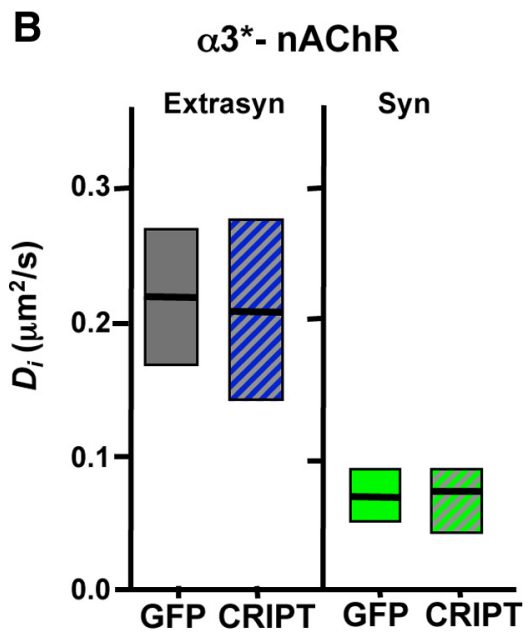

C $\alpha 7-\mathrm{nAChR}$

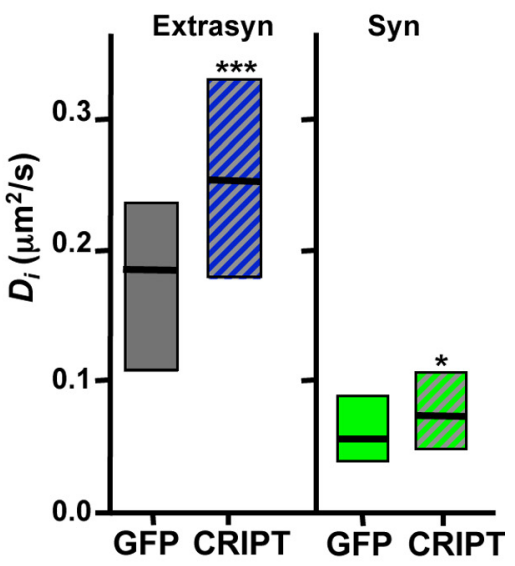

$\alpha 7-n A C h R$ $\alpha 3^{*}$-nAChR

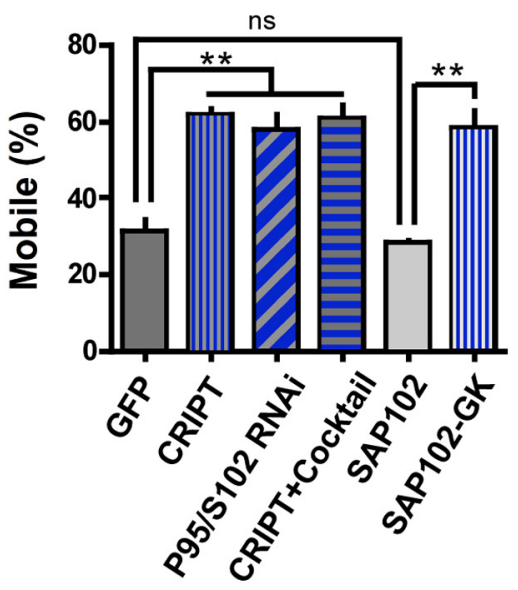

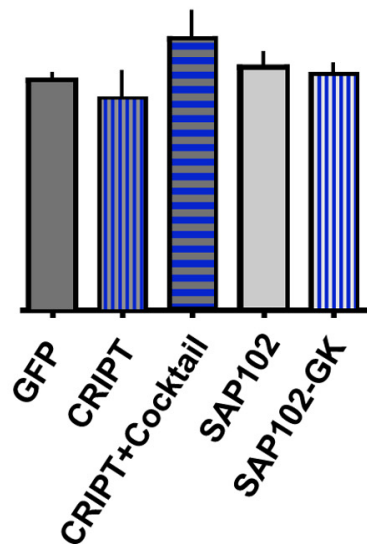

Figure 5. Regulation of $n A C h R$ mobility by PDZ-containing proteins. $A, Q D-\alpha 3^{*} n A C h R$ trajectory (red) crossing synaptic spaces labeled with MitoTracker (green) on a CG neurite expressing CRIPT (blue). Scale bar: $1 \mu \mathrm{m}$. $\boldsymbol{B}$, Median $D_{\mathrm{i}}$ values $( \pm 25-75 \%$ erquartile range) for $\alpha 3^{*}$-nAChRs in extrasynaptic and synaptic space on neurites expressing GFP (control) or CRIPT ( $n=$ xpressing GFP, CRIPT, PSD-95/SAP102-RNAi (P95/S102), SAP102, or SAP102-GFP (mean \pm SEM; $n=40-69$ total QDs from $2-6$ separate platings). Cocktail, Nocodazole (10 $\mu \mathrm{m})$, latrunculin A (3 $\mu \mathrm{M})$, and COase $(2 \mathrm{U} / \mathrm{ml})$.

untransfected controls and to neurons transfected with a construct expressing GFP; no differences were seen between the latter two (supplemental Fig. 8, available at www.jneurosci.org as supplemental material).

CRIPT expression had no effect on the diffusion parameters of mobile $\alpha 3^{\star}$-nAChRs (Fig. $5 A, B$ ) but clearly increased the diffusion of $\alpha 7$-nAChRs both in synaptic and extrasynaptic space (Fig. $5 C$; supplemental Movie 3, available at www.jneurosci.org as supplemental material). Median $D_{\mathrm{i}}$ values were $0.078 \mu \mathrm{m}^{2} / \mathrm{s}$ and $0.253 \mu \mathrm{m}^{2} / \mathrm{s}$ for synaptic and extrasynaptic space, respectively ( $p<0.05, p<0.001$ vs GFP; MW test). No significant differences were seen for $\alpha 3^{*}$-nAChRs or for $\alpha 7$-nAChRs with respect to synaptic dwell time or frequency of transition between synaptic and extrasynaptic space (supplemental Fig. 9, available at www. jneurosci.org as supplemental material). CRIPT expression, however, doubled the fraction of mobile $\alpha 3^{\star}$-nAChRs (Fig. 5D), 
increasing it from $30 \pm 5 \%$ in controls to $62 \pm 2 \%(p<0.05, t$ test) in neurites of CRIPT-transfected neurons. We corroborated the target of CRIPT action as being two specific members of the PSD-95 family: transfecting the neurons with an RNAi construct (PSD-95/SAP102-RNAi) that knocked down PSD-95 and SAP102 levels (Neff et al., 2009) had a similar effect on the $\alpha 3^{*}$ nAChR mobile fraction (Fig. 5D). No additional receptors were mobilized even when the disruptive treatments were combined: CRIPT transfection for PDZ scaffolds, nocodazole for microtubules, latrunculin A for F-actin, and COase for lipid rafts. The proportion of mobile $\alpha 3^{\star}$-nAChRs was the same as that seen with CRIPT expression alone (Fig. 5D). Notably, transfecting cells with a SAP102 construct that lacked a GK domain (SAP102-GK) acted as a dominant negative, replicating the effects of PSD-95/ SAP102-RNAi; overexpressing full-length SAP102 had no effect (Fig. 5D). None of the treatments produced a change in the fraction of $\alpha 7$-nAChRs that was mobile.

The results show that PDZ-containing proteins differentially affect the mobilities of $\alpha 3^{\star}$-nAChRs and $\alpha 7$-nAChRs, effectively discriminating on the basis of subunit composition. They constrain the rates of diffusion for mobile $\alpha 7$-nAChRs but not for mobile $\alpha 3^{\star}$-nAChRs, and conversely, they increase the size of the $\alpha 3^{\star}$-nAChR immobile fraction via a GK domain without affecting this parameter for $\alpha 7$-nAChRs.

\section{Mobility of $\alpha 7$-nAChRs on chick sympathetic ganglion neurons}

To assess the generality of these results, experiments were also performed with chick sympathetic ganglion neurons in culture. The neurons express $\alpha 7$-nAChRs that can be tagged with Biot$\alpha$ Bgt and QDs and followed through synaptic and extrasynaptic spaces on neurites. Analyzing the trajectories and calculating the $D_{\mathrm{i}}$ values as described above for CG neurons indicated again a slower mobility for $\alpha 7$-nAChRs in synaptic space, compared to extrasynaptic space (Fig. 6A, supplemental Fig. 10, available at www.jneurosci.org as supplemental material). $D_{\mathrm{i}}$ values of 0.064 $\mu \mathrm{m}^{2} / \mathrm{s}$ and $0.133 \mu \mathrm{m}^{2} / \mathrm{s}$ were obtained for synaptic and extrasynaptic trajectories, respectively $(n=196,264)$. The mean synaptic $\mathrm{D}_{\mathrm{i}} \mathrm{s}$ were equivalent on sympathetic and CG neurites, but the extrasynaptic $\mathrm{D}_{\mathrm{i}} \mathrm{s}$ were different $(p<0.001$, MW test). COase treatment produced no change in the mobility of $\alpha 7$-nAChRs either in synaptic or extrasynaptic space, in contrast to its effects on CG neurons (Fig. 6A). Disrupting the actin cytoskeleton with latrunculin $\mathrm{A}$, however, produced increases in the diffusion rates of $\alpha 7$-nAChRs both in synaptic and extrasynaptic space, and the increases were comparable to those seen for $\alpha 7-n A C h R s$ on CG neurons. The treatments produced no changes in transition frequency or synaptic dwell time (supplemental Fig. 11, available at www.jneurosci.org as supplemental material). The results indicate that the general features of $\alpha 7$-nAChR mobility are common between the two cell types but that regulatory controls can also be cell type specific.

\section{Discussion}

The lateral mobility of glutamate receptors on the surface can be a critical determinant shaping synaptic responses (Ehlers et al., 2007; Heine et al., 2008; Kessels and Malinow, 2009; Makino and Malinow, 2009). In addition to this role at nicotinic synapses, nAChR mobility may also determine receptor localization at and modulation of non-nicotinic synapses (McGehee et al., 1995; Gray et al., 1996; Alkondon and Albuquerque, 2001; Fabian-Fine et al., 2001; Ji et al., 2001; Levy and Aoki, 2002; Le Magueresse et al., 2006; Wanaverbecq et al., 2007; Zhang and Berg, 2007). We
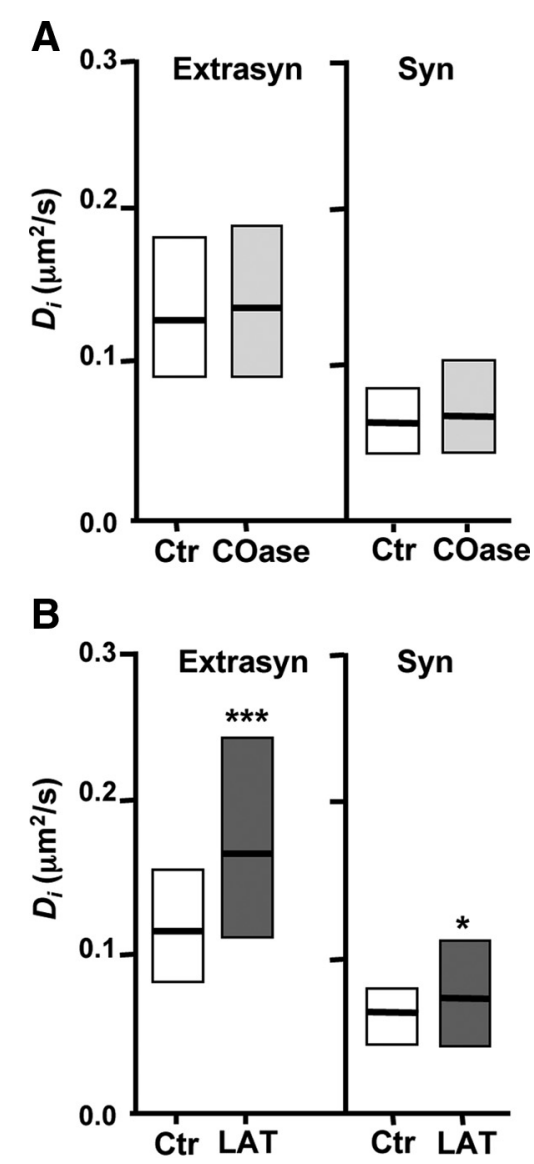

Figure 6. Lateral diffusion of surface $\alpha 7-n A C h R s$ in synaptic and extrasynaptic space on sympathetic ganglion neurites. $\boldsymbol{A}$, Median $D_{\mathrm{i}}$ values $[ \pm 25-75 \%$ interquartile range (IQR)] for extrasynaptic ( $n=193-264)$ and synaptic $(n=91-196)$ trajectories in control conditions (Ctr, $0.1 \%$ DMSO) or after cholesterol depletion with cholesterol oxidase ( $2 \mathrm{U} / \mathrm{ml}$, COase). B, Median $D_{\mathrm{i}}$ values ( $\left.\pm 25-75 \% \mathrm{IQR}\right)$ for extrasynaptic $(n=170-207)$ and synaptic $(n=102-121)$ trajectories in control conditions ( $\mathrm{Ctr}, 0.1 \% \mathrm{DMSO})$ or after disruption of F-actin with latrunculin $\mathrm{A}(3 \mu \mathrm{M}, \mathrm{LAT})$.

used QDs for single-particle tracking of nAChRs to examine their mobility on the neuron surface. We find that substantial fractions of both $\alpha 3^{*}$-nAChRs and $\alpha 7$-nAChRs are mobile on the surface, that they are constrained but not immobile when in synaptic space, and that they transition between synaptic and extrasynaptic domains. Both $\alpha 3^{*}$-nAChRs and $\alpha 7$-nAChRs also have substantial proportions of immobile receptors relatively concentrated in synaptic space. Immobile $\alpha 3^{\star}$-nAChRs, but not $\alpha 7$-nAChRs, can be liberated in part by disruption of lipid rafts and PDZ scaffolds. These same components, and to a lesser extent cytoskeletal elements, differentially constrain the mobile receptor populations depending on cell type, local domain, and receptor subunit composition. The results demonstrate a multiplicity of factors determining receptor location (Fig. 7).

On mature CG neurons in vivo, $\alpha 3^{*}$-nAChRs, but not $\alpha 7$ nAChRs, are concentrated at postsynaptic densities. Most $\alpha 7$ nAChRs and some $\alpha 3^{\star}$-nAChRs are localized on somatic spines embedded within lipid rafts and are activated by "ectopic" release from large calyx-like terminals engulfing the neurons (Jacob and Berg, 1983; Wilson Horch and Sargent, 1995; Shoop et al., 1999, 2002; Brusés et al., 2001; Coggan et al., 2005; Sargent, 2009). Here we examined receptor trafficking on CG neurites that are innervated in culture, as are CG projections at comparable stages in vivo (Landmesser and Pilar, 1972; Liu et al., 2006). Both 
$\alpha 3^{\star}$-nAChRs and $\alpha 7$-nAChRs traverse synaptic space on neurites, but the "synaptic" $\alpha 7$-nAChRs seen here could be perisynaptic at the ultrastructural level; $\alpha 3^{\star}$-nAChRs generate most of the synaptic response in culture (Chen et al., 2001; Conroy et al., 2003).

The diffusion rates found here for mobile $\alpha 3^{*}$-nAChRs and $\alpha 7$-nAChRs fall within ranges reported previously for membrane components traversing synapses (Groc and Choquet, 2008). The threefold difference in synaptic vs extrasynaptic diffusion is comparable to that reported both for AMPA receptors (Ehlers et al., 2007) and EAG1 voltagegated potassium channels (Gómez-Varela et al., 2010). A report that used photobleaching of fluorescent ligands to examine $\alpha 7$-nAChR migration in vivo also found them to be mobile and to exchange between synaptic and extrasynaptic compartments on neurons (McCann et al., 2008).

Most striking was the discovery of immobile $\alpha 3^{\star}$-nAChRs preferentially concentrated in synaptic space and that they could be freed up in part by specific treatments. The parallel decrements in immobile $\alpha 3^{\star}$-nAChRs and in $\alpha 3^{\star}$-nAChRs clusters with COase treatment suggests a functional link between the two. The fact that receptor clusters appeared to be lost "all-ornone," rather than simply diminishing in size or staining intensity, suggests a lipid-dependent threshold for receptor immobilization.

The postsynaptic membrane complex has previously been shown to contain transmembrane components that restrict diffusion, as well as scaffold networks that anchor receptors (Kim and Sheng, 2004; Charrier et al., 2006; Renner et al., 2009). The latter includes PSD-95 family members that regulate AMPA receptor mobility (Bats et al., 2007). The lipid environment also restricts mobility by increasing local membrane viscosity (Marguet et al., 2006; Allen et al., 2007) and by concentrating components that tether receptors, such as palmitoylated PSD-95 and the sequestration of AMPA receptors (ElHusseini et al., 2002). Links to the cytoskeleton help secure the postsynaptic membrane complex (Feng and Zhang, 2009).

The methods used here to depolymerize microtubules, collapse F-actin, and disrupt PDZ scaffolds containing PSD-95 family members are relatively specific and commonly used. Disruption of lipid rafts was achieved either with COase to destroy cholesterol or incubation with $\mathrm{M} \beta \mathrm{CD}$. COase treatment is a gentle strategy, minimally disturbing membrane composition while depriving rafts of a necessary component (Scheiffele et al., 1997; Harder et al., 1998; Keller and Simons, 1998). Other cholesterolprotein interactions, however, may contribute to nAChR constraint (Gimpl et al., 2002; Allen et al., 2007). The fact that COase treatment did not increase $\alpha 7$-nAChR mobility on sympathetic neurites, though F-actin disruption did, indicates that cell types vary in their constraining mechanisms and that cholesterol depletion need not be toxic.

Both cholesterol depletion by COase or $\mathrm{M} \beta \mathrm{CD}$ and disruption of postsynaptic PDZ scaffolds by CRIPT or PSD-95/SAP102 RNAi selectively freed up a portion of immobile $\alpha 3^{*}$-nAChRs but not immobile $\alpha 7$-nAChRs on CG neurons. The fraction of $\alpha 3^{*}$ $\mathrm{nAChRs}$ that remained immobile on neurites after treatment was comparable in size to the fraction of immobile $\alpha 7$-nAChRs found under all conditions. CRIPT had no effect on the lateral diffusion of already mobile $\alpha 3^{*}$-nAChRs. Paradoxically, it did increase the mobility of $\alpha 7$-nAChRs without changing the proportion of $\alpha 7$ nAChRs that was mobile. Combining a mixture of disrupters with the CRIPT expression (to acutely disrupt microtubules, F-actin, and lipid rafts in addition to chronic disruption of PDZlinks) produced no further decrease in the fraction of immobile receptors. The CRIPT and COase treatments may have generated equivalent outcomes because they targeted a shared mechanism, e.g., the clustering of palmitoylated PDZ-proteins in a lipid raft (El-Husseini et al., 2002). The receptor-specific effects caused by disrupting PDZ scaffolds may be determined by the individual PSD-95 family members that interact with $\alpha 3^{*}$-nAChRs versus $\alpha 7$-nAChRs, conferring different types of constraint (Conroy et al., 2003). The fact that the SAP102-GK construct acted as a dominant negative provided evidence that the PDZ scaffold constrains receptor mobility by linking them to sites via a GK domain. It has recently been shown that the GK domain of SAP102 is, in fact, responsible for stabilizing the protein at the postsynaptic density (Zheng et al., 2010).

Mechanisms shown here to constrain receptor mobility have been shown to stabilize receptor clusters. Disruption of lipid rafts and collapse of F-actin, for example, each disperses the large $\alpha 7$ nAChR clusters found on freshly dissociated CG neuron cell bodies (Shoop et al., 2000; Brusés et al., 2001; Liu et al., 2008). Disruption of PSD-95 family PDZ scaffolds in CG neurons via CRIPT expression or PSD-95/SAP102 RNAi significantly decreases synaptic $\alpha 3^{\star}$-nAChRs in culture (Neff et al., 2009). Disruption of PDZ scaffolds also interferes with signal transduction and downstream signaling by $\mathrm{nAChRs}$, indicating the importance of receptor positioning (Conroy et al., 2003). Further, PSD95/SAP102 RNAi decreases paired-pulse depression at synapses on CG neurons (Neff et al., 2009). Some of this latter effect may 
reflect increased receptor mobility providing rapid receptor exchange that diminishes the effects of desensitization, a phenomenon reported for AMPA receptors (Heine et al., 2008; Frischknecht et al., 2009). Lateral mobility would appear to be important for recruiting nAChRs to desired locations if receptor localization can then be stabilized.

Changes in receptor mobility did not necessarily induce a measurable change in either synaptic dwell time or frequency of transitions. This was true for diffusion of mobile $\alpha 7-n A C h R s$ on CG neurons following CRIPT disruption of PDZ scaffolds. Similarly, F-actin collapse by latrunculin A increased diffusion of mobile $\alpha 7$-nAChRs without changing either their synaptic dwell time or transition frequency. The results suggest that synaptic retention of mobile receptors may not simply reflect slower movement. Instead the receptors may be physically constrained either by a molecular border around the space or by a constraint that tethers them within the space (O'Connell et al., 2006; Triller and Choquet, 2008). This would be consistent with the observed MSD plots asymptotically approaching maximum values.

The large cytoplasmic loop of neuronal nAChRs can be critical for determining receptor location (Williams et al., 1998). Heteropentameric $\alpha 3^{\star}$-nAChRs on CG neurons are heterogeneous with respect to subunit composition. All contain $\alpha 3$ and $\beta 4$ subunits, but only some contain $\beta 2$ subunits and some, but perhaps not all, contain $\alpha 5$ subunits (Conroy and Berg, 1995). This heterogeneity may explain why $\alpha 3^{*}$-nAChRs do not respond as a homogeneous population to disruptions of the cytoskeleton, lipid rafts, or PDZ scaffolds. Even $\alpha 7$-nAChRs, which were thought to be exclusively homopentameric (Drisdel and Green, 2000), may in some cases be heteropentameric (Khiroug et al., 2002; Liu et al., 2009). Alternatively, the finding that not all receptors of a given class appear to be constrained by the same component may result from the restraining component being present in limited amounts.

In the CNS multiple kinds of nAChRs exist, and they exert numerous effects depending on location and synaptic target (Picciotto et al., 1995; Newhouse et al., 1997; Bannon et al., 1998; Marubio et al., 1999; Mansvelder and McGehee, 2002; Picciotto and Zoli, 2002; Raggenbass and Bertrand, 2002; Maskos et al., 2005; Bitner et al., 2007; Teper et al., 2007). Lateral mobility allows nAChRs to be available for quick recruitment. Our results suggest that subunit-specific interactions with cytoskeletal and scaffold components are likely to be key determinants in constraining otherwise mobile nAChRs to unique locations according to individual receptor subtype and cell identity.

\section{References}

Akaaboune M, Grady RM, Turney S, Sanes JR, Lichtman JW (2002) Neurotransmitter receptor dynamics studied in vivo by reversible photounbinding of fluorescent ligands. Neuron 34:865-876.

Alkondon M, Albuquerque EX (2001) Nicotinic acetylcholine receptors $\alpha 7$ and $\alpha 4 \beta 2$ subtypes differentially control GABAergic input to CA1 neurons in rat hippocampus. J Neurophysiol 86:3043-3055.

Allen JA, Halverson-Tamboli RA, Rasenick MM (2007) Lipid raft microdomains and neurotransmitter signalling. Nat Rev Neurosci 8:128-140.

Anderson MJ, Cohen MW (1977) Nerve-induced and spontaneous redistribution of acetylcholine receptors on cultured muscle cells. J Physiol 268:757-773.

Aravanis AM, Pyle JL, Tsien RW (2003) Single synaptic vesicles fusing transiently and successively without loss of identity. Nature 423:643-647.

Axelrod D, Ravdin PM, Podleski TR (1978) Control of acetylcholine receptor mobility and distribution in cultured muscle membranes. A fluorescence study. Biochim Biophys Acta 511:23-38.

Bannon AW, Decker MW, Holladay MW, Curzon P, Donnelly-Roberts D, Puttfarcken PS, Bitner RS, Diaz A, Dickenson AH, Porsolt RD, Williams M, Arneric SP (1998) Broad-spectrum, non-opioid analgesic activity by selective modulation of neuronal nicotinic acetylcholine receptors. Science 279:77-81.

Bats C, Groc L, Choquet D (2007) The interaction between Stargazin and PSD-95 regulates AMPA receptor surface trafficking. Neuron 53:719-734.

Bertrand D, Galzi JL, Devillers-Thiéry A, Bertrand S, Changeux J-P (1993) Mutations at two distinct sites within the channel domain M2 alter calcium permeability of neuronal $\alpha 7$ nicotinic receptor. Proc Natl Acad Sci U S A 90:6971-6975.

Bitner RS, Bunnelle WH, Anderson DJ, Briggs CA, Buccafusco J, Curzon P, Decker MW, Frost JM, Gronlien JH, Gubbins E, Li J, Malysz J, Markosyan S, Marsh K, Meyer MD, Nikkel AL, Radek RJ, Robb HM, Timmermann D, Sullivan JP, et al. (2007) Broad-spectrum efficacy across cognitive domains by $\alpha 7$ nicotinic acetylcholine receptor agonism correlates with activation of ERK1/2 and CREB phosphorylation pathways. J Neurosci 27:10578-10587.

Brusés JL, Chauvet N, Rutishauser U (2001) Membrane lipid rafts are necessary for the maintenance of the $\alpha 7$ nicotinic acetylcholine receptor in somatic spines of ciliary neurons. J Neurosci 21:504-512.

Charrier C, Ehrensperger MV, Dahan M, Lévi S, Triller A (2006) Cytoskeleton regulation of glycine receptor number at synapses and diffusion in the plasma membrane. J Neurosci 26:8502-8511.

Chen M, Pugh PC, Margiotta JF (2001) Nicotinic synapses formed between chick ciliary ganglion neurons in culture resemble those present on the neurons in vivo. J Neurobiol 47:265-279.

Coggan JS, Bartol TM, Esquenazi E, Stiles JR, Lamont S, Martone ME, Berg DK, Ellisman MH, Sejnowski TJ (2005) Ectopic neurotransmitter release at a neuronal synapse. Science 309:446-451.

Conroy WG, Berg DK (1995) Neurons can maintain multiple classes of nicotinic acetylcholine receptors distinguished by different subunit compositions. J Biol Chem 270:4424-4431.

Conroy WG, Berg DK (1998) Nicotinic receptor subtypes in the developing chick brain: appearance of a species containing the $\alpha 4, \beta 2$, and $\alpha 5$ gene products. Mol Pharmacol 53:392-401.

Conroy WG, Liu Z, Nai Q, Coggan JS, Berg DK (2003) PDZ-containing proteins provide a functional postsynaptic scaffold for nicotinic receptors in neurons. Neuron 38:759-771.

Conroy WG, Nai Q, Ross B, Naughton G, Berg DK (2007) Postsynaptic neuroligin enhances presynaptic inputs at neuronal nicotinic synapses. Dev Biol 307:79-91.

Dajas-Bailador F, Wonnacott S (2004) Nicotinic acetylcholine receptors and the regulation of neuronal signaling. Trends Pharmacol Sci 25:317-324.

Downing JE, Role LW (1987) Activators of protein kinase C enhance acetylcholine receptor desensitization in sympathetic ganglion neurons. Proc Natl Acad Sci U S A 84:7739-7743.

Drisdel RC, Green WN (2000) Neuronal $\alpha$-bungarotoxin receptors are $\alpha 7$ subunit homomers. J Neurosci 20:133-139.

Edidin M (2003) The state of lipid rafts: from model membranes to cells. Annu Rev Biophys Biomol Struct 32:257-283.

Ehlers MD, Heine M, Groc L, Lee MC, Choquet D (2007) Diffusional trapping of GluR1 AMPA receptors by input-specific synaptic activity. Neuron 54:447-460.

El-Husseini AE-D, Schnell E, Dakoji S, Sweeney N, Zhou Q, Prange O, Gauthier-Campbell C, Aguilera-Moreno A, Nicoll RA, Bredt DS (2002) Synaptic strength regulated by palmitate cycling on PSD-95. Cell 108:849-863.

Fabian-Fine R, Skehel P, Errington ML, Davies HA, Sher E, Stewart MG, Fine A (2001) Ultrastructural distribution of the $\alpha 7$ nicotinic acetylcholine receptor subunit in rat hippocampus. J Neurosci 21:7993-8003.

Farías GG, Vallés AS, Colombres M, Godoy JA, Toledo EM, Lukas RJ, Barrantes FJ, Inestrosa NC (2007) Wnt-7a induces presynaptic colocalization of $\alpha 7$-nicotinic acetylcholine receptors and adenomatous polyposis coli in hippocampal neurons. J Neurosci 27:5313-5325.

Feng W, Zhang M (2009) Organization and dynamics of PDZ-domainrelated supramodules in the postsynaptic density. Nat Rev Neurosci 10:87-99.

Frischknecht R, Heine M, Perrais D, Seidenbecher CI, Choquet D, Gundelfinger ED (2009) Brain extracellular matrix affects AMPA receptor lateral mobility and short-term synaptic plasticity. Nat Neurosci 12:897-904.

Gimpl G, Burger K, Fahrenholz F (2002) A closer look at the cholesterol sensor. Trends Biochem Sci 27:596-599.

Gómez-Varela D, Kohl T, Schmidt M, Rubio ME, Kawabe H, Nehring RB, 
Schäfer S, Stühmer W, Pardo LA (2010) Characterization of Eag1 channel lateral mobility in rat hippocampal cultures by single-particletracking with quantum dots. PLoS One 5:e8858.

Gray R, Rajan AS, Radcliffe KA, Yakehiro M, Dani JA (1996) Hippocampal synaptic transmission enhanced by low concentrations of nicotine. Nature 383:713-716.

Groc L, Choquet D (2008) Measurement and characteristics of neurotransmitter receptor surface trafficking (review). Mol Membr Biol 25:344-352.

Harder T, Scheiffele P, Verkade P, Simons K (1998) Lipid domain structure of the plasma membrane revealed by patching of membrane components. J Cell Biol 141:929-942.

Heine M, Groc L, Frischknecht R, Béique JC, Lounis B, Rumbaugh G, Huganir RL, Cognet L, Choquet D (2008) Surface mobility of postsynaptic AMPARs tunes synaptic transmission. Science 320:201-205.

Jacob MH, Berg DK (1983) The ultrastructural localization of a-bungarotoxin binding sites in relation to synapses on chick ciliary ganglion neurons. J Neurosci 3:260-271.

Ji D, Lape R, Dani JA (2001) Timing and location of nicotinic activity enhances or depresses hippocampal synaptic plasticity. Neuron 31:131-141.

Keller P, Simons K (1998) Cholesterol is required for surface transport of influenza virus hemagglutinin. J Cell Biol 140:1357-1367.

Kessels HW, Malinow R (2009) Synaptic AMPA receptor plasticity and behavior. Neuron 61:340-350.

Khiroug SS, Harkness PC, Lamb PW, Sudweeks SN, Khiroug L, Millar NS, Yakel JL (2002) Rat nicotinic ACh receptor alpha7 and beta2 subunits co-assemble to form functional heteromeric nicotinic receptor channels. J Physiol 540:425-434.

Kim E, Sheng M (2004) PDZ domain proteins of synapses. Nat Rev Neurosci 5:771-781.

Kusumi A, Sako Y, Yamamoto M (1993) Confined lateral diffusion of membrane receptors as studied by single particle tracking (nanovid microscopy). Effects of calcium-induced differentiation in cultured epithelial cells. Biophys J 65:2021-2040.

Landmesser L, Pilar G (1972) The onset and development of transmission in the chick ciliary ganglion. J Physiol 222:691-713.

Le Magueresse C, Safiulina V, Changeux JP, Cherubini E (2006) Nicotinic modulation of network and synaptic transmission in the immature hippocampus investigated with genetically modified mice. J Physiol 576:533546.

Levy RB, Aoki C (2002) $\alpha 7$ Nicotinic acetylcholine receptors occur at postsynaptic densities of AMPA receptor-positive and -negative excitatory synapses in rat sensory cortex. J Neurosci 22:5001-5015.

Liu Q, Huang Y, Xue F, Simard A, DeChon J, Li G, Zhang J, Lucero L, Wang M, Sierks M, Hu G, Chang Y, Lukas RJ, Wu J (2009) A novel nicotinic acetylcholine receptor subtype in basal forebrain cholinergic neurons with high sensitivity to amyloid peptides. J Neurosci 29:918-929.

Liu Z, Neff RA, Berg DK (2006) Sequential interplay of nicotinic and GABAergic signaling guides neuronal development. Science 314:16101613.

Liu Z, Conroy WG, Stawicki TM, Nai Q, Neff RA, Berg DK (2008) EphB receptors co-distribute with a nicotinic receptor subtype and regulate nicotinic downstream signaling in neurons. Molec Cell Neurosci 38:236-244.

Makino H, Malinow R (2009) AMPA receptor incorporation into synapses during LTP: the role of lateral movement and exocytosis. Neuron 64:381-390

Mansvelder HD, McGehee DS (2002) Cellular and synaptic mechanisms of nicotine addiction. J Neurobiol 53:606-617.

Margiotta JF, Berg DK (1982) Functional synapses are established between ciliary ganglion neurones in dissociated cell culture. Nature 296:152-154.

Marguet D, Lenne PF, Rigneault H, He HT (2006) Dynamics in the plasma membrane: how to combine fluidity and order. EMBO J 25:3446-3457.

Marubio LM, del Mar Arroyo-Jimenez M, Cordero-Erausquin M, Léna C, Le Novère N, de Kerchove d'Exaerde A, Huchet M, Damaj MI, Changeux JP (1999) Reduced antinociception in mice lacking neuronal nicotinic receptor subunits. Nature 398:805-810.

Maskos U, Molles BE, Pons S, Besson M, Guiard BP, Guilloux J-P, Evrard A, Cazala P, Cormier A, Mameli-Engvall M, Dufour N, Cloëz-Tayarani I, Bemelmans A-P, Mallet J, Gardier AM, David V, Faure P, Granon S, Changeux J-P (2005) Nicotine reinforcement and cognition restored by targeted expression of nicotinic receptors. Nature 436:103-107.

McCann CM, Tapia JC, Kim H, Coggan JS, Lichtman JW (2008) Rapid and modifiable neurotransmitter receptor dynamics at a neuronal synapse in vivo. Nat Neurosci 11:807-815.

McGehee DS, Heath MJS, Gelber S, Devay P, Role LW (1995) Nicotine enhancement of fast excitatory synaptic transmission in CNS by presynaptic receptors. Science 269:1692-1696.

Neff RA 3rd, Conroy WG, Schoellerman JD, Berg DK (2009) Synchronous and asynchronous transmitter release at nicotinic synapses are differentially regulated by postsynaptic PSD-95 proteins. J Neurosci 29:15770-15779.

Newhouse PA, Potter A, Levin ED (1997) Nicotinic system involvement in Alzheimer's and Parkinson's diseases. Implications for therapeutics. Drugs Aging 11:206-228.

Newpher TM, Ehlers MD (2008) Glutamate receptor dynamics in dendritic microdomains. Neuron 58:472-497.

Nishi R, Berg DK (1981) Two components from eye tissue that differentially stimulate the growth and development of ciliary ganglion neurons in cell culture. J Neurosci 1:505-513.

O'Connell KMS, Rolig AS, Whitesell JD, Tamkun MM (2006) Kv2.1 potassium channels are retained within dynamic cell surface microdomains that are defined by a perimeter fence. J Neurosci 26:9609-9618.

Parker MJ, Zhao S, Bredt DS, Sanes JR, Feng G (2004) PSD93 regulates synaptic stability at neuronal cholinergic synapses. J Neurosci 24:378-388.

Passafaro M, Sala C, Niethammer M, Sheng M (1999) Microtubule binding by CRIPT and its potential role in the synaptic clustering of PSD-95. Nat Neurosci 2:1063-1069.

Picciotto MR, Zoli M (2002) Nicotinic receptors in aging and dementia. J Neurobiol 53:641-655.

Picciotto MR, Zoli M, Léna C, Bessis A, Lallemand Y, Le Novère N, Vincent P, Pich EM, Brûlet P, Changeux JP (1995) Abnormal avoidance learning in mice lacking functional high-affinity nicotine receptor in the brain. Nature 374:65-67.

Raggenbass M, Bertrand D (2002) Nicotinic receptors in circuit excitability and epilepsy. J Neurobiol 53:580-589.

Renner M, Choquet D, Triller A (2009) Control of the postsynaptic membrane viscosity. J Neurosci 29:2926-2937.

Rosenberg MM, Yang F, Giovanni M, Mohn JL, Temburni MK, Jacob MH (2008) Adenomatous polyposis coli plays a key role, in vivo, in coordinating assembly of the neuronal nicotinic postsynaptic complex. Mol Cell Neurosci 38:138-152.

Sage D, Neumann FR, Hediger F, Gasser SM, Unser M (2005) Automatic tracking of individual fluorescence particles: application to the study of chromosome dynamics. IEEE Trans Image Process 14:1372-1383.

Sargent PB (2009) Nicotinic receptors concentrated in the subsynaptic membrane do not contribute significantly to synaptic currents at an embryonic synapse in the chicken ciliary ganglion. J Neurosci 29:3749-3759.

Scheiffele P, Roth MG, Simons K (1997) Interaction of influenza virus haemagglutinin with sphingolipid-cholesterol membrane domains via its transmembrane domain. EMBO J 16:5501-5508.

Séguéla P, Wadiche J, Dineley-Miller K, Dani JA, Patrick JW (1993) Molecular cloning, functional properties, and distribution of rat brain $\alpha 7$ : a nicotinic cation channel highly permeable to calcium. J Neurosci 13:596-604.

Shinawi M, Schaaf CP, Bhatt SS, Xia Z, Patel A, Cheung SW, Lanpher B, Nagl S, Herding HS, Nevinny-Stickel C, Immken LL, Patel GS, German JR, Beaudet AL, Stankiewicz P (2009) A small recurrent deletion within $15 \mathrm{q} 13.3$ is associated with a range of neurodevelopmental phenotypes. Nat Genet 41:1269-1271.

Shoop RD, Martone ME, Yamada N, Ellisman MH, Berg DK (1999) Neuronal acetylcholine receptors with $\alpha 7$ subunits are concentrated on somatic spines for synaptic signaling in embryonic chick ciliary ganglia. J Neurosci 19:692-704.

Shoop RD, Yamada N, Berg DK (2000) Cytoskeletal links of neuronal acetylcholine receptors containing $\alpha 7$ subunits. J Neurosci 20:4021-4029.

Shoop RD, Esquenazi E, Yamada N, Ellisman MH, Berg DK (2002) Ultrastructure of a somatic spine mat for nicotinic signaling in neurons. J Neurosci 22:748-756.

Temburni MK, Rosenberg MM, Pathak N, McConnell R, Jacob MH (2004) Neuronal nicotinic synapse assembly requires the adenomatous polyposis coli tumor suppressor protein. J Neurosci 24:6776-6784.

Teper Y, Whyte D, Cahir E, Lester HA, Grady SR, Marks MJ, Cohen BN, Fonck C, McClure-Begley T, McIntosh JM, Labarca C, Lawrence A, Chen F, Gantois I, Davies PJ, Petrou S, Murphy M, Waddington J, Horne MK, 
Berkovic SF, et al. (2007) Nicotine-induced dystonic arousal complex in a mouse line harboring a human autosomal-dominant nocturnal frontal lobe epilepsy mutation. J Neurosci 27:10128-10142.

Triller A, Choquet D (2008) New concepts in synaptic biology derived from single-molecule imaging. Neuron 59:359-374.

Vernallis AB, Conroy WG, Berg DK (1993) Neurons assemble acetylcholine receptors with as many as three kinds of subunits while maintaining subunit segregation among receptor subtypes. Neuron 10:451-464.

Wanaverbecq N, Semyanov A, Pavlov I, Walker MC, Kullmann DM (2007) Cholinergic axons modulate GABAergic signaling among hippocampal interneurons via postsynaptic $\alpha 7$ nicotinic receptors. J Neurosci 27:5683-5693.

Williams BM, Temburni MK, Schwartz Levey M, Bertrand S, Bertrand D, Jacob MH (1998) The long internal loop of the $\alpha 3$ subunit targets nAChRs to subdomains within individual synapses on neurons in vivo. Nat Neurosci 1:557-562.

Wilson Horch HL, Sargent PB (1995) Perisynaptic surface distribution of multiple classes of nicotinic acetylcholine receptors on neurons in the chicken ciliary ganglion. J Neurosci 15:7778-7795.

Young SH, Poo MM (1983) Rapid lateral diffusion of extrajunctional acetylcholine receptors in the developing muscle membrane of Xenopus tadpole. J Neurosci 3:225-231.

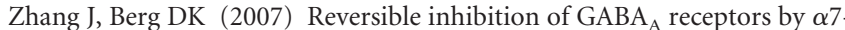
containing nicotinic receptors on vertebrate postsynaptic neurons. J Physiol 579:753-763.

Zhang T, Zhang L, Liang Y, Siapas AG, Zhou F-M, Dani JA (2009) Dopamine signaling differences in the nucleus accumbens and dorsal striatum exploited by nicotine. J Neurosci 29:4035-4043.

Zhang Z-W, Vijayaraghavan S, Berg DK (1994) Neuronal acetylcholine receptors that bind $\alpha$-bungarotoxin with high affinity function as ligandgated ion channels. Neuron 12:167-177.

Zheng C-Y, Petralia RS, Wang Y-X, Kachar B, Wenthold RJ (2010) SAP102 is a highly mobile MAGUK in spines. J Neurosci 30:4757-4766. 